UDC 94(470.45)«1939/1944»:314.9

Submitted: 19.09.2018

LBC 63.3(2P-4Вог)62-1

Accepted: 06.12.2018

\title{
TERRITORY AND POPULATION OF THE STALINGAD REGION IN 1939-1944
}

\author{
Sergey G. Sidorov \\ Volgograd State University, Volgograd, Russian Federation
}

\begin{abstract}
Introduction. The Stalingrad region was founded on the $5^{\text {th }}$ of December 1936. In 1939-1944 the territory and population of the region underwent changes. It included a number of areas of the Volga German ASSR and the Kalmyk ASSR eliminated in 1941-1943. The Astrakhan district was transformed into an independent region, the Germans and the Kalmyks were deported to the eastern regions of the country. Methods and materials. The author of the article uses statistical materials of the All-Union Population Census of the USSR of 1939 and the information and statistical reference book Stalingrad region (1939-1943). Figures and facts. A comparative historical method is widely used to reveal the peculiarities of the national composition of the population of the Stalingrad region and its neighboring regions, and to show the changes that took place in different areas of the region during 1939-1944. For the first time in research literature, 5 groups of rural areas of the region are distinguished. Analysis. The national composition of the population of Stalingrad, Astrakhan and rural areas of the region is investigated, and a comparison with neighboring regions is conducted. Representatives of more than 80 nationalities lived in the Stalingrad region, among them Russians (87.6 \%), Ukrainians (3.6 \%), Kazakhs (3.2 \%), Tatars (2.8 \%) and Germans (1.0\%) prevailed. Special attention is paid to the change in the territory and composition of the region's population after the annexation of 7 areas of the eliminated Volga German ASSR in 1941 and 2 areas of the eliminated Kalmyk ASSR in 1944 and the deportation of Germans and Kalmyks to the eastern regions of the country. Results. The war led to a change in the national composition and a substantial reduction in the number of residents in the region. It took about 20 years to overcome the consequences of the war and deportation to restore the population of the Stalingrad region.
\end{abstract}

Key words: Stalingrad region, Astrakhan district, national structure of the population, administrative-territorial division, deportation of Germans, deportation of Kalmyks.

Citation. Sidorov S.G. Territory and Population of the Stalingad Region in 1939-1944. Vestnik Volgogradskogo gosudarstvennogo universiteta. Seriya 4, Istoriya. Regionovedenie. Mezhdunarodnye otnosheniya [Science Journal of Volgograd State University. History. Area Studies. International Relations], 2019, vol. 24, no. 1, pp. 140-154. (in Russian). DOI: https://doi.org/10.15688/jvolsu4.2019.1.12

УДК 94(470.45)«1939/1944»:314.9

Дата поступления статьи: 19.09.2018

ББК 63.3(2Р-4Вог)62-1

Дата принятия статьи: 06.12.2018

\section{ТЕРРИТОРИЯ И НАСЕЛЕНИЕ СТАЛИНГРАДСКОЙ ОБЛАСТИ В 1939-1944 ГОДАХ}

\section{Сергей Григорьевич Сидоров}

Волгоградский государственный университет, г. Волгоград, Российская Федерация

\footnotetext{
Аннотация. В статье показаны административно-территориальное деление, численность и национальный состав населения Сталинградской области в 1939 г. и последующие их изменения в 1941-1944 годах. В отличие от соседних Воронежской, Ростовской и Саратовской областей, состоявших только из районов, в состав области входил Астраханский округ (8 сельских районов из 66), который в конце 1943 г. был преобразован в самостоятельную область. На территории области находилось более 7 тысяч населенных пунктов, из которых большая его часть была сосредоточена в Сталинграде и Астрахани, остальные 5 городов и 12 рабочих поселков были небольшими по численности. Площади сельских районов и численность населения были неравно(?) мерными. Наиболее крупные и густонаселенные районы входили в состав Астраханского округа, которые
} 
составили 23,9 \% территории и 26,9 \% населения области. В статье исследован национальный состав населения Сталинграда, Астрахани и сельских районов области, проведено сравнение с соседними областями. В Сталинградской области проживали представители более 80 национальностей, среди которых преобладали русские $(87,6 \%)$, украинцы (3,6 \%), казахи (3,2 \%), татары $(2,8 \%)$ и немцы $(1,0 \%)$. Большое внимание уделено изменению территории и составу населения области после присоединения в 1941 г. 7 районов ликвидированной АССР немцев Поволжья и в 1944 г. 2 районов ликвидированной Калмыцкой АССР и депортации немцев и калмыков в восточные районы страны. На преодоление последствий войны и депортации для восстановления численности населения области потребовалось около 20 лет.

Ключевые слова: Сталинградская область, Астраханский округ, национальный состав населения, административно-территориальное деление, депортация немцев, депортация калмыков.

Цитирование. Сидоров С. Г. Территория и население Сталинградской области в 1939-1944 годах // Вестник Волгоградского государственного университета. Серия 4, История. Регионоведение. Международные отношения. - 2019. - Т. 24, № 1. - C. 140-154. - DOI: https://doi.org/10.15688/jvolsu4.2019.1.12

Введение. 5 декабря 1936 г. в СССР была принята Конституция, которая установила новое административно-территориальное деление страны. Из состава РСФСР были выведены 3 автономные республики - Казахская, Киргизская и Каракалпакская. Первые две были преобразованы в союзные республики, последняя вошла в состав Узбекской ССР. Ряд автономных областей стали автономными республиками (Кабардино-Балкарская, Коми, Марийская, Северо-Осетинская, Чечено-Ингушская). 7 краев преобразованы в области, в их числе оказался и Сталинградский край. Территория и население вновь образованной Сталинградской области в 19391944 гг. не оставались неизменными. За 5 лет на территории области произойдут колоссальные изменения, связанные с включением в ее состав ряда районов ликвидированных в 19411943 гг. АССР немцев Поволжья и Калмыцкой АССР, выделением Астраханского округа в самостоятельную область, оккупацией ряда сельских и городских районов областного центра в период Сталинградской битвы, депортацией немцев и калмыков в восточные районы страны. Об этом и пойдет речь в данной статье.

Методы и материалы. В основу сведений о довоенной истории области положены материалы Всесоюзной переписи населения СССР 1939 г., проведенной всего через 2 года после «неудачной» переписи 1937 года. Если перепись 1937 г. учитывала только наличное население, то перепись 1939 г. учитывала как наличное, так и постоянное население (тех, кто проживал в данной местности, но отсутствовал в момент переписи). При под- ведении итогов переписи была введена поправка на вероятный недоучет населения. К числу фактически переписанных граждан были добавлены более 3 млн человек. Такой подход позволил завысить конечные сведения о количестве жителей страны. Проведенные расчеты учеными Института демографии Национального исследовательского университета «Высшая школа экономики» показали, что фальсифицированная добавка к действительной численности населения СССР составила 1741580 человек, или 1,05 \% [1]. Это нужно учитывать при анализе представленных в статье таблиц. Наряду с материалами переписи населения 1939 г. автором использованы документы информационно-статистического справочника «Сталинградская область (19391943). Цифры и факты» [15], содержащего источники из фондов Государственного архива Волгоградской области, Центра документации новейшей истории Волгоградской области и других.

В статье широко применяется сравнительно-исторический метод, позволяющий раскрыть особенности национального состава населения Сталинградской и соседних с ней Воронежской, Ростовской и Саратовской областей, сравнить территорию, численность и национальный состав населения Сталинграда и Астрахани, сельских районов Астраханского округа и других районов Сталинградской области, раскрыть естественный и механический прирост населения области за 1939-1940 гг., показать изменения, произошедшие в национальном составе и численности населения в разных районах области за 1939-1944 годы. При этом впервые в исследовательской лите- 
ратуре выделяются 5 групп сельских районов области: оккупированные полностью или частично в период Сталинградской битвы; прифронтовые; тыловые; тыловые районы, включенные в состав области после ликвидации АССР немцев Поволжья 7 сентября 1941 г.; районы, включенные в состав области после ликвидации Калмыцкой АССР 27 декабря 1943 года. Выделение вышеназванных групп позволило раскрыть особенности развития различных районов области, влияние войны и депортации немцев и калмыков на изменение состава жителей и плотность населения области.

Анализ. Сталинградская область образована из Сталинградского края 5 декабря 1936 года. На территории области, составлявшей 135,4 тыс. кв. км [13, с. 109], находилось более 7000 населенных пунктов разных типов. В их число входили 56 станиц, 3675 хуторов, 346 поселков, 46 деревень, 263 села, 2 кишлака, 130 аулов, 4 хатона, 124 кочевых стойбища, 295 поселков совхозов и МТС, большое количество поселений (1 139 колхозных, 27 промышленных предприятий, 339 железнодорожного, водного и воздушного транспорта, 139 рыболовных промыслов, 154 лесохозяйственных, 176 культурно-бытовых) и 21 других населенных пунктов. Большинство населенных пунктов (6 409) были небольшими с числом жителей от 10 до 500 человек. Лишь в 641 население превышало 500 чел. [12, с. 22].

Территория области административно делилась на 66 сельских районов ${ }^{1}$, населенные пункты в которых входили в состав 1041 сельских советов [13, с. 109].

16 июля 1937 г. постановлением ВЦИК в структуре Сталинградской области был об- разован Астраханский округ. В его состав вошло 8 сельских районов: Владимировский, Володарский, Енотаевский, Икрянинский, Камызякский, Красноярский, Наримановский и Харабалинский. Территория Астраханского округа составляла 32,3 тыс. кв. км, или 23,9 \% всей площади области. Такое изменение позволяло областным властям осуществлять более оперативное руководство всей хозяйственной, политической и культурной деятельностью партийных и советских органов власти в округе [15, с. 24].

Численность населения области по состоянию на 1 января 1939 г. достигла 2288139 чел., из них городского - 892648 и сельского 1395 431. Доля женщин в составе населения области равнялась 53,2 \% (среди городских жителей $-52,8 \%$, среди сельских жителей $53,6 \%)$.

Доля городского населения в Сталинградской области (39\%) была выше, чем в среднем по СССР (32,9\%), РСФСР $(33,7 \%)$, соседних Воронежской $(18,7 \%)$ и Саратовской (37\%) областях, и незначительно ниже, чем в Ростовской области $(43,7$ \%). Всего на территории области имелось 19 городских поселений - городов и рабочих поселков. 87,5 \% городских жителей проживало в 7 городах.

Самым крупным городом был областной центр - Сталинград (табл. 1), в котором на 1 января 1939 г. насчитывалось 445312 чел., или около 19,5 \% всех жителей области. В состав Сталинграда входило 7 районов: Баррикадный (34 801 чел.), Ворошиловский (107987 чел.), Дзержинский (70 058 чел.), Ерманский (36 104 чел.), Кировский (66 940 чел.), Красно-

Таблича 1

Города Сталинградской области по состоянию на 1 января 1939 г. $^{2}$

\begin{tabular}{|l|c|c|c|}
\hline \multicolumn{1}{|c|}{ Наименование } & Год основания & С какого года город & Число жителей, чел. \\
\hline Всего городских жителей & & & 892648 \\
\hline в том числе жителей городов & & & 780892 \\
\hline в\% от городских жителей & & & 87,5 \\
\hline $\begin{array}{l}\text { в том числе в городах: } \\
\text { Сталинград }\end{array}$ & 1589 & 1780 & 445312 \\
\hline Астрахань & 1558 & 1717 & 253595 \\
\hline Дубовка & 1734 & 1803 & 10649 \\
\hline Камышин & 1668 & 1780 & 23981 \\
\hline Серафимович & 1589 & 1933 & 8262 \\
\hline Урюпинск & 1618 & 1929 & 21686 \\
\hline Фролово & 1859 & 1936 & 17407 \\
\hline
\end{tabular}


октябрьский (65 302 чел.), Тракторозаводской (64 120 чел.) [15, с. 24].

Второе место по численности населения (253 595 чел.) занимал окружной центр - город Астрахань, в котором находилось 11,1 \% всего населения области и 41,2 \% населения округа. Город Астрахань состоял из 4 городских районов: Кировский (41 548 чел.), Микояновский (85 104 чел.), Сталинский (77 723 чел.) и Трусовский (49 220 чел.).

Другие 5 городов области, являющихся районными центрами, были небольшими с численностью населения от 10 до 24 тысяч человек.

Большинство из 12 рабочих поселков на территории области возникли в 30 -е гг. на месте ранее существовавших населенных пунктов в ходе проведения индустриализации (табл. 2). 7 рабочих поселков находилось в
Астраханском округе, и только 5 - в других сельских районах. При этом рабочие поселки Астраханского округа, за исключением Петропавловского (10 876 чел.), были небольшими с населением от 2 до 6 тысяч чел. Рабочие поселки на остальной территории области были значительно крупнее и по численности населения превышали число жителей городов Серафимович и Дубовка.

Общая численность населения Астраханского округа (615 207 чел.) составляла 26,9 \% всего населения Сталинградской области (табл. 3). По состоянию на 1 января 1939 г. 47 \% жителей округа (288 861 чел.) относилось к городским жителям [8]. Из 66 сельских районов области в Астраханский округ входило только 8 (12,1\%). Это были большие густонаселенные районы, в которых проживало от 30 до

Рабочие поселки Сталинградской области по состоянию на 1 января 1939 г. $^{2}$

Таблийа 2

\begin{tabular}{|l|l|c|c|}
\hline \multicolumn{1}{|c|}{ Сельский район } & \multicolumn{1}{c|}{$\begin{array}{c}\text { Наименование } \\
\text { рабочего поселка }\end{array}$} & $\begin{array}{c}\text { С какого года } \\
\text { рабочий поселок }\end{array}$ & $\begin{array}{c}\text { Число } \\
\text { жителей, чел. }\end{array}$ \\
\hline Котельниковский & Котельниковский & 1929 & 15460 \\
\hline Краснослободский & Красная Слобода & 1938 & 15593 \\
\hline Михайловский & Михайловка & 1936 & 17741 \\
\hline Николаевский & Николаевск & 1936 & 12452 \\
\hline Новоаннинский & Ново-Аннинск & 1936 & 15244 \\
\hline \multicolumn{4}{|c|}{ Астраханский округ } \\
\hline Владимировский & Верхний Баскунчак & 1936 & 5854 \\
\hline & Нижний Баскунчак & 1927 & 4461 \\
\hline & Петропавловский & 1936 & 10876 \\
\hline Икрянинский & Мумра & 1938 & 4061 \\
\hline & Оранжерейный & 1938 & 4778 \\
\hline & Трудфронт & 1938 & 3028 \\
\hline Камызякский & Кировский & 1938 & 2208 \\
\hline
\end{tabular}

Таблииа 3

Численность населения Астраханского округа на 1 января 1939 г. $^{3}$

\begin{tabular}{|l|r|r|r|r|c|}
\hline \multicolumn{1}{|c|}{ Район } & $\begin{array}{c}\text { Город- } \\
\text { ское, } \\
\text { чел. }\end{array}$ & $\begin{array}{c}\text { Сельское, } \\
\text { чел. }\end{array}$ & $\begin{array}{c}\text { Все население, } \\
\text { чел. }\end{array}$ & $\begin{array}{c}\text { Территория, } \\
\text { тыс. кв. км }\end{array}$ & $\begin{array}{c}\text { Плотность } \\
\text { населения, } \\
\text { чел. } \\
\text { на 1 кв. км }\end{array}$ \\
\hline Сталинградская область & 892648 & 1395491 & 2288139 & 135,4 & 16,9 \\
\hline Астраханский округ & 288861 & 326346 & 615207 & 32,3 & 19,0 \\
\hline г. Астрахань & 253595 & 0 & 253595 & & \\
\hline Сельские районы: & 35266 & 326346 & 361612 & 32,3 & 11,2 \\
\hline Владимировский & 21191 & 37488 & 58679 & 6,5 & 9,0 \\
\hline Володарский & 0 & 56328 & 56328 & 2,2 & 25,6 \\
\hline Енотаевский & 0 & 28631 & 28631 & 5,1 & 5,0 \\
\hline Икрянинский & 11867 & 37129 & 48996 & 1,0 & 49,0 \\
\hline Камызякский & 2208 & 48834 & 51042 & 2,1 & 24,3 \\
\hline Красноярский & 0 & 39813 & 39813 & 5,6 & 7,1 \\
\hline Наримановский & 0 & 40116 & 40116 & 1,8 & 22,3 \\
\hline Харабалинский & 0 & 38007 & 38007 & 8,0 & 4,8 \\
\hline
\end{tabular}


60 тыс. человек. При этом население сельских районов распределялось неравномерно. Если в среднем в сельской местности округа на 1 кв. км приходилось 11,2 чел., то в Икрянинском районе - 49,0, в Володарском - 25,6, в Камызякском - 24,3, Наримановском - 22,3, а в Красноярском - только 7,1, Енотаевском 5,0 , Харабалинском - 4,8 чел. [15, с. 211-212].

Сельские районы области, не входившие в состав Астраханского округа, были в основном меньше как по размеру территории, так и по численности населения. Самым большим по размеру был Эльтонский район, территория которого составляла около 6,5 тыс. кв. км. Однако в районе проживало всего лишь 20261 человек. Территории остальных районов колебались в пределах от 0,4 до 4 и более тыс. кв. км. При этом только площадь двух районов (Калачевский, Черноярский) превышала 4 тыс. кв. км, трех (Ворошиловский, Ленинский, Николаевский) -3 тыс. кв. км, двенадцати -2 тыс. кв. км. Размеры остальных 40 сельских районов составляли от 0,4 (Paковский) до 2 тыс. кв. км [13, с. 109-110].

Плотность населения сельских районов (без Астраханского округа) в среднем равнялась 10,3 чел. на 1 кв. км. Заселенность районов была неравномерной. В 26 районах плотность населения была ниже средней. Особенно низкой она была в Эльтонском (3,2 чел. на 1 кв. км), Кайсацком $(3,3)$ и Котельниковском
$(4,2)$ районах. Вместе с тем в нескольких районах плотность населения была более чем в два раза выше, чем средняя по области. К таким районам относились Краснослободский $(22,8)$, Хоперский $(23,9)$ и Еланский $(27,8)$. Высокая плотность населения наблюдалась также в Руднянском $(18,9)$, Бударинском $(18,6)$, Молотовском $(17,7)$, Добринском $(17,1)$ и Лемешкинском $(16,7)$ районах.

В Сталинградской области к началу 1939 г. проживали представители более 82 национальностей, из которых 16 - численностью более 500 человек, 5 - более 20 тысяч человек. Самыми многочисленными были русские - 2003299 чел. $(87,6 \%)$, за ними шли украинцы - 82509 чел. $(3,6 \%)$, казахи - 72471 чел. (3,2 \%), татары 64223 чел. (2,8 \%) и немцы-23 751 чел. (1,0\%).

Доля представителей этих пяти национальностей составляла 96 \%. На 6 месте находились евреи (9 623 чел.), на седьмом - калмыки (8 502 чел.), доля которых в общем составе населения области составляла всего $0,4 \%$ и $0,37 \%$ соответственно.

Национальный состав населения Сталинградской области по сравнению с граничащими с ней областями имел как общие черты, так и отличительные особенности. Во всех областях преобладали представители русского и украинского народа, которые в Воронежской составляли $99 \%$, Ростовской - 94,1\%, Саратовской $86,9 \%$ всего населения (табл. 4).

Национальный состав населения Воронежской, Ростовской, Саратовской и Сталинградской областей по итогам Всесоюзной переписи населения 1939 г., чел. ${ }^{4}$

\begin{tabular}{|l|c|c|c|c|}
\hline Национальность & $\begin{array}{c}\text { Воронежская } \\
\text { область }\end{array}$ & $\begin{array}{c}\text { Ростовская } \\
\text { область }\end{array}$ & $\begin{array}{c}\text { Саратовская } \\
\text { область }\end{array}$ & $\begin{array}{c}\text { Сталинградская } \\
\text { область }\end{array}$ \\
\hline Все население & 3551329 & 2892580 & 1798514 & 2288139 \\
\hline Русские & 3113269 & 2613000 & 1563443 & 2003299 \\
\hline$B \%$ & 87,7 & 90,3 & 86,9 & 87,6 \\
\hline Украинцы & 402710 & 110660 & 96562 & 82509 \\
\hline$B \%$ & 11,3 & 3,8 & 5,4 & 3,6 \\
\hline Немцы & 5361 & 32968 & 42970 & 23751 \\
\hline Евреи & 11105 & 33024 & 7411 & 9623 \\
\hline Татары & 1798 & 10216 & 21329 & 64223 \\
\hline Белорусы & 4381 & 8188 & 3122 & 2712 \\
\hline Армяне & 1318 & 49339 & 826 & 3170 \\
\hline Казахи & 834 & 1713 & 23436 & 72471 \\
\hline Мордовцы & 961 & 1724 & 23098 & 3918 \\
\hline Калмыки & 35 & 9047 & 92 & 8502 \\
\hline Другие & 9577 & 22701 & 16225 & 13961 \\
\hline
\end{tabular}


Представители национальностей, находящихся на последующих местах, в соседних областях различались. В Воронежской области это были евреи (11 105 чел.), немцы (5 361 чел.) и белорусы (4 381 чел.); в Ростовской - армяне (49 339 чел.), евреи (33 024 чел.), немцы (32 968 чел.) и татары (10 216 чел.); в Саратовской - немцы (42 970 чел.), казахи (23 436 чел.), мордовцы (23 098 чел.) и татары (21 329 чел.).

Национальный состав населения Астраханского округа и других районов Сталинградской области был неоднороден (табл. 5 и 6). В районах Астраханского округа русские и украинцы составляли только 78,8 \% всего населения, в остальных районах $-95,7 \%$. В большинстве районов с казачьим населением доля русских составляла 97-99\%.

В области имелись районы с большой концентрацией представителей тех или иных национальностей. Так, из 82509 украинцев, зарегистрированных на территории области, 64600 чел. (78,3 \%) проживало в 8 сельских районах (56 068 чел.) и Сталинграде (8 532 чел.). При этом в Мачешанском районе доля украин- цев (8 851 чел.) составляла 54,3 \% всего населения, Лемешкинском (9 295 чел.) - $52 \%$, Еланском (17 225 чел.) - 47,5 \%, Молотовском (7 930 чел.) - 46,8 \%, Руднянском (7 359 чел.) 24,5 \%, Калининском (2 477 чел.) - 13,3 \%, Неткачевском (1 547 чел.) - 9,7\%, Вязовском (1 384 чел.) - 7,2 \%. В Астраханском округе украинцев было очень мало, там их доля составляла 5,2 \%, в остальных районах области $94,8 \%$.

Подавляющее число казахов (61 170 чел. из 72471 чел., или 84,4\%) проживало в Астраханском округе. Особенно много их было в Володарском районе (26 157 чел.), в котором они составляли $46,4 \%$ всего населения. Вне Астраханского округа казахи компактно проживали главным образом в трех заволжских районах: Эльтонском (2 921 чел.) - 14,4\%, Кайсацком (1 596 чел.) - 18,9 \% и Николаевском (1 390 чел.) - 4,1\% всего населения.

75,9 \% татар, проживающих на территории области, также находились в Астраханском округе. Вне округа с большой концентрацией татар можно выделить три района, в которых их доля среди населения районов была

\section{Национальный состав населения Сталинградской области по состоянию на 1 января 1939 г. $^{5}$}

\begin{tabular}{|c|c|c|c|c|c|c|}
\hline \multirow[t]{2}{*}{$\begin{array}{c}\text { Национальность, } \\
\text { чел. }\end{array}$} & \multicolumn{2}{|c|}{$\begin{array}{c}\text { Сталинградская } \\
\text { область }\end{array}$} & \multicolumn{2}{|c|}{$\begin{array}{c}\text { Без Астраханского } \\
\text { округа }\end{array}$} & \multicolumn{2}{|c|}{ Астраханский округ } \\
\hline & Итого, чел. & B \% & Итого, чел. & B \% & Итого, чел. & B \% \\
\hline Русские & 2003299 & 87,6 & 1523060 & 91,0 & 480239 & 78,1 \\
\hline Украинцы & 82509 & 3,6 & 78202 & 4,7 & 4307 & 0,7 \\
\hline Казахи & 72471 & 3,2 & 11301 & 0,7 & 61170 & 9,9 \\
\hline Татары & 64223 & 2,8 & 15489 & 0,9 & 48734 & 7,9 \\
\hline Немцы & 23751 & 1,0 & 21400 & 1,3 & 2351 & 0,4 \\
\hline Прочие & 41886 & 1,8 & 23480 & 1,4 & 18406 & 3,0 \\
\hline Всего & 2288139 & 100,0 & 1672932 & 100,0 & 615207 & 100,0 \\
\hline
\end{tabular}

Таблица 5

\section{Таблица 6}

\section{Распределение населения различных национальностей по территории} Сталинградской области по состоянию на 1 января 1939 г. ${ }^{5}$

\begin{tabular}{|c|c|c|c|c|c|c|}
\hline \multirow[t]{2}{*}{ Национальность } & \multicolumn{2}{|c|}{$\begin{array}{c}\text { Сталинградская } \\
\text { область }\end{array}$} & \multicolumn{2}{|c|}{$\begin{array}{c}\text { Без Астраханского } \\
\text { округа }\end{array}$} & \multicolumn{2}{|c|}{$\begin{array}{c}\text { Астраханский } \\
\text { округ }\end{array}$} \\
\hline & Итого, чел. & B \% & Итого, чел. & B \% & Итого, чел. & B \% \\
\hline Русские & 2003299 & 100,0 & 1523060 & 76,0 & 480239 & 24,0 \\
\hline Украинцы & 82509 & 100,0 & 78202 & 94,8 & 4307 & 5,2 \\
\hline Казахи & 72471 & 100,0 & 11301 & 15,6 & 61170 & 84,4 \\
\hline Татары & 64223 & 100,0 & 15489 & 24,1 & 48734 & 75,9 \\
\hline Немцы & 23751 & 100,0 & 21400 & 90,1 & 2351 & 9,9 \\
\hline Прочие & 41886 & 100,0 & 23480 & 56,1 & 18406 & 43,9 \\
\hline Всего & 2288139 & 100,0 & 1672932 & 73,1 & 615207 & 26,9 \\
\hline
\end{tabular}


заметной: Ленинский (1 804 чел.) - 8,2 \%, Красноармейский (1 674 чел.) - 8,4\%, Черноярский (1 465 чел.) - 5,6 \%.

Немцы проживали во многих районах, но наибольшая концентрация их наблюдалась в 4 районах: Николаевском (3 146 чел.) - 9,2 \%, Камышинском (2 071 чел.) - 4,4 \%, Фроловском (1 902 чел.) - 6,5\% и Ольховском (1 329 чел.) - 7,2 \% населения. Доля немцев в Астраханском округе составляла лишь $9,9 \%$, остальные $90,1 \%$ проживали в других районах области.

На территории области имелись районы компактного проживания калмыков - Ворошиловский (1 055 чел.), Енотаевский (1 356 чел.), Красноармейский (820 чел.); мордовцев Пролейский (657 чел.); корейцев - Камызякский (1 356 чел.); туркменов - Наримановский (1 117 чел.). Основная масса евреев проживала в Астрахани (4 014 чел.) и Сталинграде (3 789 чел.).

Национальный состав населения областного и окружного центров различался (табл. 7). В Сталинграде доля русских составляла $92,6 \%$, украинцев - 1,9\%, немцев $1,5 \%$, татар - 1,3\%. В Астрахани доля рус- ских была меньше и составляла лишь 84,9 \%, татар $-8,9 \%$, украинцев $-1 \%$, казахов и немцев - по $0,7 \%$.

В 1930-е гг. в стране большое внимание уделялось развитию школьного образования. Если в годы первой пятилетки решалась проблема введения всеобщего обязательного начального обучения, то в планах третьей пятилетки предусматривалось ввести всеобщее семилетнее образование в сельской местности и всеобщее среднее в городах. Численность неграмотного населения старше 6 лет к началу 1939 г. составляла только 19,7 \% (табл. 8). Этот показатель был лучше, чем в Воронежской области $(23,5 \%)$, но уступал другим соседним областям - Саратовской $(17,3$ \%) и Ростовской $(16,4 \%)$.

В то же время следует подчеркнуть, что наибольшая доля неграмотных приходилась на людей 55 лет и старше (см. табл. 9).

В возрастной группе от 55 до 59 лет доля неграмотных составляла $52,7 \%$, старше 60 лет $-66,9$ \%. Эти показатели также были лучше, чем в Воронежской области, но уступали показателям Ростовской и Саратовской областей.

Таблица 7

Национальный состав населения г. Сталинграда и г. Астрахани по состоянию на 1 января 1939 г. $^{5}$

\begin{tabular}{|c|c|c|c|c|}
\hline \multirow{2}{*}{ Национальность } & \multicolumn{2}{|c|}{ г. Сталинград } & \multicolumn{2}{|c|}{ г. Астрахань } \\
\hline & Итого, чел. & B \% & Итого, чел. & B \% \\
\hline Русские & 412236 & 92,6 & 215199 & 84,9 \\
\hline Украинцы & 8532 & 1,9 & 2526 & 1,0 \\
\hline Казахи & 794 & 0,2 & 1683 & 0,7 \\
\hline Татары & 5775 & 1,3 & 22606 & 8,9 \\
\hline Немцы & 6812 & 1,5 & 1869 & 0,7 \\
\hline Прочие & 11163 & 2,5 & 9712 & 3,8 \\
\hline Всего & 445312 & 100,0 & 253595 & 100,0 \\
\hline
\end{tabular}

Таблииа 8

Численность неграмотного населения Воронежской, Ростовской,

Саратовской и Сталинградской областей по итогам Всесоюзной переписи населения 1939 г., чел. ${ }^{6}$

\begin{tabular}{|c|c|c|c|c|}
\hline Возраст (лет) & $\begin{array}{c}\text { Воронежская } \\
\text { область }\end{array}$ & $\begin{array}{c}\text { Ростовская } \\
\text { область }\end{array}$ & $\begin{array}{c}\text { Саратовская } \\
\text { область }\end{array}$ & $\begin{array}{c}\text { Сталинградская } \\
\text { область }\end{array}$ \\
\hline Всего населения & 3551329 & 2892580 & 1798514 & 2288139 \\
\hline До 6 лет & 561289 & 428583 & 278802 & 346578 \\
\hline Старше 6 лет & 2990040 & 2463997 & 1519712 & 1941561 \\
\hline из них неграмотных & 701257 & 404905 & 263024 & 385606 \\
\hline в\% & 23,5 & 16,4 & 17,3 & 19,7 \\
\hline
\end{tabular}


Главным достижением 30-х гг. в области просвещения был почти полный охват детей школьным обучением (табл. 10). Среди детей в возрасте от 9 до 17 лет доля неграмотных составляла менее $2 \%$.

К началу 1941 г. за два года численность населения области выросла на 65,8 тыс. чел. и составила 2 353,9 тыс. человек. При этом городское население росло гораздо более быстрыми темпами, чем сельское (табл. 11).

Число жителей городов и рабочих поселков выросло на 48,9 тыс. чел., или на 5,5 \%, сельской местности - только на 16,9 тыс., или на 1,2 \%. На 1 января 1941 г. число жителей Сталинграда и Астрахани выросло на 30,7 тыс. чел., других городов и рабочих поселков - на 18,2 тыс. чел. (см. табл. 12). Темпы роста населения в районных городах и рабочих поселках оказались выше $(9,6 \%)$, чем в областном и окружном центрах $(4,4 \%)$.

Более быстрые темпы роста численности городских жителей объясняются механическим приростом населения, переездом селян в города и рабочие поселки. При этом из других обла-

Таблииа 9

Численность неграмотного населения старше 55 лет Воронежской, Ростовской, Саратовской и Сталинградской областей по итогам Всесоюзной переписи населения 1939 г., чел. ${ }^{6}$

\begin{tabular}{|l|c|c|c|c|}
\hline \multicolumn{1}{|c|}{ Возраст, лет } & $\begin{array}{c}\text { Воронежская } \\
\text { область }\end{array}$ & $\begin{array}{c}\text { Ростовская } \\
\text { область }\end{array}$ & $\begin{array}{c}\text { Саратовская } \\
\text { область }\end{array}$ & $\begin{array}{c}\text { Сталинградская } \\
\text { область }\end{array}$ \\
\hline $55-59$ & 110771 & 81323 & 54164 & 73173 \\
\hline из них неграмотных & 65646 & 36362 & 26345 & 38566 \\
\hline в\% & 59,3 & 44,7 & 48,6 & 52,7 \\
\hline 60 и старше & 238904 & 187993 & 113228 & 159031 \\
\hline из них неграмотных & 170319 & 114926 & 72169 & 106398 \\
\hline в\% & 71,3 & 61,1 & 63,7 & 66,9 \\
\hline
\end{tabular}

Таблийа 10

Распределение неграмотного населения Сталинградской области в возрасте от 9 до 17 лет по состоянию на 1 января 1939 г. ${ }^{7}$

\begin{tabular}{|c|c|c|c|}
\hline Возраст, лет & Всего, чел. & Неграмотных, чел. & В \% \\
\hline 9 & 48436 & 2148 & 4,4 \\
\hline 10 & 56806 & 1166 & 2,1 \\
\hline 11 & 56988 & 686 & 1,2 \\
\hline 12 & 64862 & 698 & 1,1 \\
\hline 13 & 54737 & 774 & 1,4 \\
\hline 14 & 55089 & 803 & 1,5 \\
\hline 15 & 49005 & 823 & 1,7 \\
\hline 16 & 34830 & 731 & 2,1 \\
\hline 17 & 32641 & 729 & 2,2 \\
\hline Всего детей в возрасте & & & \\
от 9 до 17 лет & 453394 & 8558 & 1,9 \\
\hline
\end{tabular}

Изменение численности населения Сталинградской области за 1939-1940 гг., тыс. чел. ${ }^{8}$

\begin{tabular}{|l|c|c|c|c|}
\hline \multicolumn{1}{|c|}{ Категории населения } & 01.01 .1939 г. & 01.01 .1941 г. & Прирост & В \% \\
\hline Все население & 2288,1 & 2353,9 & 65,8 & 2,9 \\
\hline Сельское население & 1395,5 & 1412,4 & 16,9 & 1,2 \\
\hline Городское население & 892,6 & 941,5 & 48,9 & 5,5 \\
\hline В том числе: & & & & \\
\hline Сталинград и Астрахань & 698,9 & 729,6 & 30,7 & 4,4 \\
\hline другие города и рабочие поселки & 193,7 & 211,9 & 18,2 & 9,6 \\
\hline
\end{tabular}


стей страны в Сталинградскую область прибыло лишь 0,6 тыс. человек. Из сельской местности области и других регионов в города и рабочие поселки переехало 28,4 тыс. чел., из которых 13,8 тыс. чел. поселилась в Сталинграде и Астрахани, 15,2 тыс. чел. - в других городах и рабочих поселках.

В 1941 г. после начала Великой Отечественной войны территория и население Сталинградской области увеличились. Указом Президиума Верховного Совета СССР от 7 сентября 1941 г. в ее состав были переданы 7 районов (кантонов) ликвидированной АССР немцев Поволжья: Гмелинский, Добринский, Иловатский, Палласовский, Старополтавский, Франкский, Эрленбахский. В области стало 73 района. В апреле 1942 г. Добринский район переименовали в Нижне-Добринский, Франкский - в Медведицкий, Эрленбахский - в Ременниковский.

С присоединением к области новых районов к 5 существовавшим рабочим поселкам добавилось еще 2 - Кратцке и Палласовка (табл. 13).

В результате территория области выросла на 8,9 тыс. кв. км и составила 144,3 тыс. кв. км. Самыми большими из вновь вошедших в состав области были Палласовский $(2,0$ тыс. кв. км) и Гмелинский (1,6 тыс. кв. км) районы, площадь остальных районов составляла от 0,5 до 1,3 тыс. кв. км.

В присоединенных районах, по Всесоюзной переписи населения СССР 1939 г., прожи- вали лица десятков национальностей, основными из которых были немцы $(64,4 \%)$, русские (18 \%) и украинцы (12,9\%). Представители других национальностей составляли только 4,7 \% всего населения 7 районов, в том числе казахи $-1,8 \%$, калмыки - 1,2 \%. Наиболее крупными были Франкский и Добринский кантоны, в которых находилось более 29574 и 26346 жителей соответственно. В остальных 5 кантонах число жителей колебалось от 12 до 18 тыс. чел. (см. табл. 14).

Распределение населения по национальностям внутри кантонов было неравномерным. Если во Франкском (89,5 \%), Добринском $(88,1 \%)$ и Эрленбахском $(87,1 \%)$ кантонах немецкое население было преобладающим, то в Палласовском оно составляло чуть более половины (52 \%), в Старополтавском - только $18,2 \%$, а в Иловатском - лишь 3,8 \%. При этом в Иловатском кантоне русские составляли 73,6 \% всего населения, в Старополтавском $24,2 \%$. В последнем кантоне преобладали украинцы - 47,6 \%. Много украинцев проживало в Палласовском (22 \%) и в Гмелинском (16,9\%) кантонах. В этих кантонах по сравнению с другими находилось много и казахов, соответственно $4,8 \%$ и $5,5 \%$ от общей численности населения. В Старополтавском кантоне 5,3 \% населения составляли татары.

К сентябрю 1941 г. по сравнению с началом 1939 г. численность населения 7 районов, вошедших в состав Сталинградской области, уменьшилась на 8103 чел. и состави-

Таблича 12

\section{Естественный и механический прирост населения Сталинградской области} за 1939-1940 годы, тыс. чел. ${ }^{9}$

\begin{tabular}{|l|c|c|c|}
\hline \multicolumn{1}{|c|}{ Категории населения } & Общий прирост & Естественный & Механический \\
\hline Все население & 65,8 & 65,2 & 0,6 \\
\hline Сельское население & 16,9 & 45,3 & $-28,4$ \\
\hline Городское население & 48,9 & 19,9 & 29,0 \\
\hline в том числе: & & & \\
\hline Сталинград и Астрахань & 30,7 & 16,9 & 13,8 \\
\hline другие города и рабочие поселки & 18,2 & 3,0 & 15,2 \\
\hline
\end{tabular}

Таблица 13

Рабочие поселки вновь присоединенных районов бывшей АССР немцев Поволжья по состоянию на 7 сентября 1941 г. $^{10}$

\begin{tabular}{|l|l|c|c|}
\hline Сельский район & Наименование & Год основания & Число жителей в 1939 г., чел. \\
\hline Медведицкий & Кратцке & 1938 & 2188 \\
\hline Палласовский & Палласовка & 1939 & 6715 \\
\hline
\end{tabular}


ла 120032 чел. [15, с. 28-29]. Сокращение было связано, как и в целом по области, с общим уменьшением численности сельских жителей в связи с их оттоком в города и рабочие поселки.

Резкое сокращение численности населения районов произошло после выселения немцев с обжитых мест в сентябре 1941 г. в Казахстан, на Алтай и в Сибирь. Фактически эти районы сразу лишились почти двух третей населения. Особенно пострадали Медведицкий, Нижне-Добринский, Ременниковский, Гмелинский и Палласовский районы, в которых немецкое население преобладало (табл. 15).

Руководство страны и области постарались возместить убыль населения за счет эвакуированного из западных районов страны, в первую очередь из Украины. Однако принятые меры не позволили покрыть понесенные в 1941 г. потери. На 1 января 1943 г. численность населения бывших районов АССР немцев По- волжья составила 75288 чел., или $62,7 \%$ от уровня на начало сентября 1941 года. В течение 1943 г. численность населения этих районов вновь стала уменьшаться за счет того, что эвакуированные стали возвращаться на освобожденные территории. На 1 января 1944 г. в районах осталось только 61117 чел., или 50,9 \% от уровня 1941 года. При этом катастрофическим оказалось положение в Нижне-Добринском районе, в котором осталось только 18,7 \% населения от довоенного уровня. Чуть лучше положение было в Медведицком районе $38,6 \%$. Около 55 \% населения осталось в Гмелинском, Палласовском и Ременниковском районах. Лишь в Иловатском и Старополтавском районах, где до войны меньше всего проживало немцев, численность населения составляла около $90 \%$ от довоенного уровня.

Изменился национальный состав населения. Преобладающими стали русские, увеличилась численность украинцев. Так, в Ниж-

Национальный состав 7 кантонов АССР НП,

Таблиия 14 переданных в состав Сталинградской области в 1941 г. (по Всесоюзной переписи населения СССР 1939 г.) ${ }^{12}$

\begin{tabular}{|c|c|c|c|c|c|c|c|c|c|c|}
\hline \multirow[t]{2}{*}{ Район } & \multicolumn{2}{|c|}{ Итого } & \multicolumn{2}{|c|}{ Немцы } & \multicolumn{2}{|c|}{ Русские } & \multicolumn{2}{|c|}{ Украинцы } & \multicolumn{2}{|c|}{ Другие } \\
\hline & чел. & $\%$ & чел. & $\%$ & чел. & $\%$ & чел. & $\%$ & чел. & $\%$ \\
\hline Гмелинский & 15590 & 100,0 & 9766 & 62,6 & 1882 & 12,1 & 2635 & 16,9 & 1307 & 8,4 \\
\hline Добринский & 26346 & 100,0 & 23212 & 88,1 & 2244 & 8,5 & 359 & 1,4 & 531 & 2,0 \\
\hline Иловатский & 12416 & 100,0 & 467 & 3,8 & 9143 & 73,6 & 2425 & 19,5 & 381 & 3,1 \\
\hline Палласовский & 18437 & 100,0 & 9592 & 52,0 & 3197 & 17,3 & 4047 & 22,0 & 1601 & 8,7 \\
\hline Старополтавский & 13752 & 100,0 & 2497 & 18,2 & 3327 & 24,2 & 6545 & 47,6 & 1383 & 10,0 \\
\hline Франкский & 29574 & 100,0 & 26462 & 89,5 & 2172 & 7,3 & 387 & 1,3 & 553 & 1,9 \\
\hline Эрленбахский & 12020 & 100,0 & 10468 & 87,1 & 1134 & 9,4 & 172 & 1,4 & 246 & 2,1 \\
\hline Bcezo & 128135 & 100,0 & $\begin{array}{|ll|}82464 \\
\end{array}$ & 64,4 & 23099 & 18,0 & 16570 & 12,9 & 6028 & 4,7 \\
\hline
\end{tabular}

Таблииа 15

Изменение численности населения районов бывшей АССР немцев Поволжья, переданных в сентябре 1941 г. в состав Сталинградской области, за 1939-1944 гг., чел. (на 1 января года) ${ }^{13}$

\begin{tabular}{|c|c|c|c|c|}
\hline Наименование района & 1939 г. & 1941 г.* & 1943 г. & 1944 г. \\
\hline Гмелинский & 15590 & 13792 & 11180 & 7529 \\
\hline Иловатский & 12416 & 12743 & 14189 & 11498 \\
\hline Медведицкий (Франкский) & 29574 & 29534 & 10906 & 11389 \\
\hline Нижне-Добринский (Добринский)** & 26346 & 23270 & 10897 & 4351 \\
\hline Палласовский & 18437 & 17489 & 9650 & 9600 \\
\hline Ременниковский (Эрленбахский) & 12020 & 10927 & 5668 & 5987 \\
\hline Старополтавский & 13752 & 12277 & 12798 & 10763 \\
\hline Bсего & 128135 & 120032 & 75288 & 61117 \\
\hline
\end{tabular}

Примечания. * - Данные на 7 сентября 1941 г. ** - В скобках указаны старые названия кантонов. 
не-Добринском районе доля украинцев с 1,4 \% в 1939 г. выросла до 25 \% в 1944 г., в Ременниковском - с 1,4 \% до 52 \% [15, с. 209-210].

Война привела к резкому сокращению численности населения области. В Красную армию вместе с добровольцами, влившимися непосредственно в воинские части, было направлено 479821 чел. [15, с. 213].

Боевые действия на территории области в период Сталинградской битвы оставили неизгладимый след. 14 сельских районов оказались полностью или частично оккупированы, 22 района находились в прифронтовой зоне, подвергались обстрелам артиллерии и налетам вражеской авиации. 6 районов Сталинграда из 7 были полностью или частично оккупированы и почти до основания разрушены. Более 50 тыс. жителей сельских районов погибло от боевых действий [12, с. 550]. Свыше 64 тыс. чел. с территории области было вывезено в Германию [14, с. 420]. Наибольшие потери понесли оккупированные районы области. По состоянию на 1 января 1944 г. в этих районах осталось лишь 70,7 \% от численности населения 1939 года. В прифронтовых районах сокращение населения оказалось также больше, чем в тыловых районах (табл. 16).
Особенно пострадало население Сталинграда. В результате варварских бомбардировок в Сталинграде погибло 42797 мирных жителей $[14$, с. 78$]$. К моменту завершения Сталинградской битвы в городе оставалось чуть более 32 тыс. жителей.

После завершения боев на территории области в город начинают возвращаться эвакуированные жители, прибывать люди из других районов страны (табл. 17). Среди них были как квалифицированные специалисты с семьями, так и молодежь, прибывающая по комсомольской мобилизации.

За первое полугодие 1943 г. механический прирост населения Сталинграда составил 62378 человек. 45458 чел. прибыло из автономных республик, краев и областей РСФСР, из которых более половины (23 543 чел.) составляли жители Сталинградской области. К концу 1943 г. механический прирост населения Сталинграда составил 131227 чел. [15, с. 218, 219-221]. К 1 января 1944 г. число жителей Сталинграда достигло 248 тыс. чел., или 55,7 \% от уровня 1939 года. При этом население районов Сталинграда росло неравномерно. Если в неразрушенном от боевых действий Кировском районе число жителей выросло до 90 тыс.

\section{Изменение численности населения сельских районов Сталинградской области} за 1939-1944 гг. (на 1 января года), чел. ${ }^{14}$

\begin{tabular}{|l|c|c|c|}
\hline \multicolumn{1}{|c|}{ Категории районов } & 1939 г. & 1944 г. & В \% \\
\hline Районы, оккупированные в период Сталинградской битвы & 269036 & 190115 & 70,7 \\
\hline Прифронтовые районы в период Сталинградской битвы & 358687 & 328325 & 91,5 \\
\hline Тыловые районы в период Сталинградской битвы & 599897 & 571200 & 95,2 \\
\hline $\begin{array}{l}\text { Тыловые районы, включенные в состав Сталинградской облас- } \\
\text { ти после ликвидации АССР немцев Поволжья }\end{array}$ & & & \\
7 сентября 1941 г. & 128135 & 61117 & 47,7 \\
\hline $\begin{array}{l}\text { Районы, вошедшие в состав Сталинградской области после } \\
\text { ликвидации Калмыцкой АССР 27 декабря 1943 г. }\end{array}$ & 31989 & 14523 & 45,4 \\
\hline
\end{tabular}

Таблииа 17

Динамика численности населения районов Сталинграда за 1939-1944 гг., чел. ${ }^{15}$

\begin{tabular}{|l|r|r|r|r|r|}
\hline \multicolumn{1}{|c|}{ Район } & 01.01 .1939 & 02.02 .1943 & 15.07 .1943 & 01.01 .1944 & 1944 в \% к 1939 \\
\hline Баррикадный & 34801 & 76 & 6461 & 19000 & 54,6 \\
\hline Ворошиловский & 107987 & 6723 & 29839 & 40000 & 37,0 \\
\hline Дзержинский & 70058 & 3150 & 17402 & 32000 & 45,7 \\
\hline Ерманский & 36104 & 32 & 14667 & 8000 & 22,2 \\
\hline Кировский & 66940 & 22000 & 72074 & 90000 & 134,4 \\
\hline Краснооктябрьский & 65302 & 50 & 12148 & 23000 & 35,2 \\
\hline Тракторозаводский & 64120 & 150 & 16956 & 36000 & 56,1 \\
\hline \multicolumn{1}{|c|}{ Всего по городу } & 445312 & 32181 & 169547 & 248000 & 55,7 \\
\hline
\end{tabular}


$(134,4$ \% по отношению к численности 1939 г.), то в наиболее пострадавших районах оно составило только 22,2 \% (Ерманский), 35,2 \% (Краснооктябрьский), 37 \% (Ворошиловский), 45,7 \% (Дзержинский) от уровня 1939 года.

Указом Президиума Верховного Совета РСФСР от 27 декабря 1943 г. «О ликвидации Калмыцкой АССР и образовании Астраханской области в составе РСФСР» Астраханский округ преобразован в область, к Сталинградской области было присоединено 2 района бывшей Калмыцкой АССР (Малодербетовский и Сарпинский) площадью 8,3 тыс. кв. км. В области общей площадью 120,3 кв. км стало 67 сельских районов. Во вновь присоединенных районах, по Всесоюзной переписи населения 1939 г., проживало около 32 тыс. человек. 60,9\% жителей составляли русские, $38 \%$ - калмыки, 1,1 \% - представители других национальностей (табл. 18).

В конце декабря 1943 г. - начале 1944 г. калмыки были выселены с территории области, включая вновь присоединенные районы, в Омскую, Новосибирскую, Тюменскую и Свердловскую области, Красноярский и Алтайский края. В результате этого, а также потерь, понесенных в ходе боевых действий в период Сталинградской битвы, численность населения присоединенных районов значительно сократилась и составила к началу 1944 г. 14523 чел., или 45,4 \% от уровня 1939 года.

Результаты. Подводя итоги, мы можем сделать вывод, что война привела к значительному сокращению количества жителей области. Плотность сельского населения на 1 января 1944 г. по сравнению с 1939 г. снизилась с 10,1 до 7,6 чел. на 1 кв. км, или в 1,3 раза (табл. 19). При этом в районах, вошедших в состав области после ликвидации АССР немцев Поволжья и Калмыцкой АССР, плотность населения уменьшилась в 2,2 раза; в районах, оккупированных в 1942 г., - почти в 1,5 раза; в прифронтовых районах - в 1,2 раза; в тыловых районах - в 1,19 раза.

Потребовались около 20 лет, чтобы число жителей области превысило довоенный уровень. Если численность населения Сталинградской области в начале 1939 г. (без Астраханского округа и Черноярского района, который в 1947 г. передадут в состав Астраханской области, с учетом 7 районов АССР немцев Поволжья) составляла 1772619 чел., то по Всесоюзной переписи населения 1959 г. 1853928 чел. [11].

Национальный состав населения районов бывшей Калмыцкой АССР, вошедших в состав Сталинградской области 27 декабря 1943 г. (на 1 января 1939 г.), чел. ${ }^{16}$

\begin{tabular}{|c|c|c|c|c|}
\hline Национальность & Малодербетовский район & Сарпинский район & Итого & $\mathrm{B} \%$ \\
\hline Русские & 11286 & 8191 & 19477 & 60,9 \\
\hline Калмыки & 7861 & 4299 & 12160 & 38,0 \\
\hline Татары & 65 & 62 & 127 & 0,4 \\
\hline Украинцы & 69 & 40 & 109 & 0,3 \\
\hline Прочие & 79 & 37 & 116 & 0,4 \\
\hline Всего & 19360 & 12629 & 31989 & 100,0 \\
\hline
\end{tabular}

Таблицуа 19

Плотность сельского населения Сталинградской области в 1939-1944 гг. ${ }^{17}$

\begin{tabular}{|l|c|c|}
\hline \multicolumn{1}{|c|}{ Категории районов } & \multicolumn{2}{|c|}{ Плотность населения, чел. на 1 кв. км } \\
\cline { 2 - 3 } & $\begin{array}{c}\text { На 1 января } \\
1939 \text { г. }\end{array}$ & $\begin{array}{c}\text { На 1 января } \\
1944 \text { г. }\end{array}$ \\
\hline Районы, оккупированные в период Сталинградской битвы & 8,3 & 5,7 \\
\hline Прифронтовые районы в период Сталинградской битвы & 10,1 & 8,3 \\
\hline Тыловые районы в период Сталинградской битвы & 11,7 & 9,9 \\
\hline $\begin{array}{l}\text { Тыловые районы, включенные в состав области после } \\
\text { ликвидации АССР немцев Поволжья 7 сентября 1941 г. }\end{array}$ & 13,3 & 5,9 \\
\hline $\begin{array}{l}\text { Районы, вошедшие в состав области после ликвидации } \\
\text { Калмыцкой АССР 27 декабря 1943 г. }\end{array}$ & 3,8 & 1,7 \\
\hline Итого по 67 сельским районам & 10,1 & 7,6 \\
\hline
\end{tabular}




\section{ПРИМЕЧАНИЯ}

1 Алексеевский, Балыклейский, Березовский, Бударинский, Быковский, Верхнекурмоярский, Владимировский, Володарский, Ворошиловский, Вязовский, Даниловский, Добринский, Дубовский, Еланский, Енотаевский, Ждановский, Икрянинский, Иловлинский, Кагановичский, Кайсацкий, Калачевский, Калининский, Камызякский, Камышинский, Киквидзенский, Клетский, Комсомольский, Котельниковский, Красноармейский, Краснослободский, Красноярский, Кругловский, Кумылженский, Лемешкинский, Ленинский, Логовский, Мачушанский, Михайловский, Молотовский, Наримановский, Неткачевский, Нехаевский, Нижнечирский, Николаевский, Новоаннинский, Новониколаевский, Ольховский, Перелазовский, Песчанский, Подтелковский, Пролейский, Раковский, Руднянский, Серафимовичский, Сиротинский, Солодчинский, Среднеахтубинский, Сулимовский, Тормосиновский, Урюпинский, Фроловский, Харабалинский, Хоперский, Черноярский, Черышковский, Эльтонский районы.

2 Таблица составлена и подсчитана автором по данным: [8].

3 Таблица составлена автором по данным: [9; 15 , с. $76,77,86,88,95,103,114,140]$.

4 Таблица составлена и подсчитана автором по данным: [6].

5 Таблица составлена и подсчитана автором по данным: [4].

6 Таблица составлена и подсчитана автором по данным: [7].

7 Таблица составлена и подсчитана автором по данным: [2; 3].

8 Таблица составлена и подсчитана автором по данным: [9; 15, с. 169].

9 Таблица составлена и подсчитана автором по данным: [9; 15, с. 169-170, 172].

10 Таблица составлена автором по данным: [8; 15 , с. 24-25].

${ }^{11} \mathrm{~B}$ настоящее время поселок Подчинный Жирновского района с населением 145 чел. (2010 г.).

12 Таблица составлена и подсчитана автором по данным: [5].

13 Таблица составлена и подсчитана автором по данным: [9; 15, с. 26-29, 201-202, 208-210].

14 Таблица составлена и подсчитана автором по данным: [9; 15, с. 200-202, 208-210].

15 Таблица составлена и подсчитана автором по данным: [15, с. 217].

16 Таблица составлена и подсчитана автором по данным: [10].

17 Без Астраханского округа с учетом сведений районов, присоединенных к области в 1941 и 1943 годах. Таблица составлена и подсчитана автором по данным: [15, с. 109, 130, 211-212].

\section{СПИСОК ЛИТЕРАТУРЫ}

1. Богоявленский, Д. Д. О приписках в переписи в 1939 г. / Д. Д. Богоявленский. - Электрон. текстовые дан. - Режим доступа: http://www. demoscope.ru/weekly/2013/0571/arxiv01.php (дата обращения: 18.04.2018). - Загл. с экрана.

2. Всесоюзная перепись населения 1939 г. Возрастной состав населения краев, областей, автономных республик, автономных областей и округов РСФСР. - Электрон. текстовые дан. - Режим доступа: http://www.demoscope.ru/weekly/ssp/rus_ age_39.php?reg=58\&gor=3\&Submit=OK (дата обращения: 18.04.2018). - Загл. с экрана.

3. Всесоюзная перепись населения 1939 г. Распределение неграмотного населения регионов РСФСР по полу и возрасту. - Электрон. текстовые дан. - Режим доступа: http://www.demoscope.ru/ weekly/ssp/rus_ill_39.php?reg=71 (дата обращения: 18.04.2018). - Загл. с экрана.

4. Всесоюзная перепись населения 1939 г. Национальный состав населения районов, городов и крупных сел РСФСР. - Электрон. текстовые дан. Режим доступа: http://www.demoscope.ru/weekly/ ssp/rus_nac_39_ra.php?reg (дата обращения: 18.04.2018). - Загл. с экрана.

5. Всесоюзная перепись населения 1939 г. Национальный состав населения по республикам СССР. - Электрон. текстовые дан. - Режим доступа: http://www.demos cope.ru/weekly/ssp/sng_ nac_39.php?reg=5 (дата обращения: 18.04.2018).Загл. с экрана.

6. Всесоюзная перепись населения 1939 г. Национальный состав населения по регионам России. Электрон. текстовые дан. - Режим доступа: http: //www.demoscope.ru/weekly/ssp/rus_nac_39.php (дата обращения: 18.04.2018). - Загл. с экрана.

7. Всесоюзная перепись населения 1939 г. Распределение неграмотного населения регионов РСФСР по полу и возрасту. - Электрон. текстовые дан. - Режим доступа: http://www.demoscope.ru/ weekly/ssp/rus_ill_39.php?reg (дата обращения: 18.04.2018). - Загл. с экрана.

8. Всесоюзная перепись населения 1939 г. Численность городского населения СССР по городским поселениям и внутригородским районам. Электрон. текстовые дан. - Режим доступа: http: //www.demoscope.ru/weekly/ssp/rus_pop_39_3.php (дата обращения: 18.04.2018). - Загл. с экрана.

9. Всесоюзная перепись населения 1939 г. Численность наличного населения СССР по районам и городам. - Электрон. текстовые дан. - Режим доступа: http://www.demoscope.ru/weekly/ssp/rus_pop_ 39_2.php (дата обращения: 18.04.2018). -Загл. с экрана.

10. Всесоюзная перепись населения 1939 г. Национальный состав населения районов, городов и 
крупных сел РСФСР. - Электрон. текстовые дан. Режим доступа: http://www.demoscope.ru/weekly/ ssp/rus_nac_39_ra.php?reg=2215 (дата обращения: 18.04.2018). - Загл. с экрана.

11. Всесоюзная перепись населения 1959 г. Численность наличного населения городов и других поселений, районов, районных центров и крупных сельских населенных мест на 15 января 1959 года по республикам, краям и областям РСФСР. - Электрон. текстовые дан. - Режим доступа: http://www. demoscope.ru/weekly/ssp/rus59_reg1.php (дата обращения: 18.04.2018). - Загл. с экрана.

12. Павлова, Т. А. Засекреченная трагедия: гражданское население в Сталинградской битве / Т. А. Павлова. - Волгоград : Перемена, 2005. - 594 с.

13. РСФСР. Административно-территориальное деление краев, областей и автономных республик на 17 января 1939 года. - М., 1939. - 160 с.

14. Сталинградская битва. Июль 1942 - февраль 1943 : энциклопедия. - 5-е изд. - Волгоград : Издатель, 2012. -800 c.

15. Сталинградская область (1939-1943). Цифры и факты : информационно-статистический справочник. Т. 1. - Волгоград : Издатель, 2016. - 424 с.

\section{REFERENCES}

1. Bogoyavlenskiy D.D. Opripiskakh v perepisi $v 1939 \mathrm{~g}$. [About Interlineations in the Census in 1939]. URL: http://www.demoscope.ruweekly/ssp/pripiski_ 1939.doc. (accessed 18 April 2018).

2. Vsesoyuznaya perepis naseleniya $1939 \mathrm{~g}$. Vozrastnoy sostav naseleniya kraev, oblastey, avtonomnykh respublik, avtonomnykh oblastey $i$ okrugov RSFSR [The All-Union Population Census of 1939. The Age Composition of the Population of Territories, Regions, Autonomous Republics, Autonomous Regions and Districts of the RSFSR]. URL: http://www.demoscope.ru/weekly/ssp/rus age_39.php?reg=58\&gor $=3 \&$ Submit $=$ OK. (accessed 18 April 2018).

3. Vsesoyuznaya perepis naseleniya $1939 \mathrm{~g}$. Raspredelenie negramotnogo naseleniya regionov RSFSR po polu $i$ vozrastu [The All-Union Population Census of 1939. Distribution of Illiterate Population of the RSFSR Regions by Sex and Age]. URL: http:// www.demoscope.ru/weekly/ssp/rus ill 39.php?reg=71. (accessed 18 April 2018).

4. Vsesoyuznaya perepis naseleniya $1939 \mathrm{~g}$. Natsionalnyy sostav naseleniya rayonov, gorodov $i$ krupnykh sel RSFSR [The All-Union Population Census of 1939. National Composition of the Population of Areas, Cities and Large Villages of the RSFSR]. URL: http://www.demoscope.ru/weekly/ssp/ rus_nac_39_ra.php?reg. (accessed 18 April 2018).
5. Vsesoyuznaya perepis naseleniya $1939 \mathrm{~g}$. Natsionalnyy sostav naseleniya po respublikam SSSR [The All-Union Population Census of 1939. National Composition of the Population in the Republics of the USSR]. URL: http://www.demoscope.ru/weekly/ssp/ sng_nac_39.php?reg=5. (accessed 18 April 2018).

6. Vsesoyuznaya perepis naseleniya $1939 \mathrm{~g}$. Natsionalnyy sostav naseleniya po regionam Rossii [The All-Union Population Census of 1939. National Composition of the Population in the Regions of Russia]. URL: http://www.demoscope.ru/weekly/ssp/ rus_nac_39.php. (accessed 18 April 2018).

7. Vsesoyuznaya perepis naseleniya $1939 \mathrm{~g}$. Raspredelenie negramotnogo naseleniya regionov RSFSR po polu i vozrastu [The All-Union Population Census of 1939. Distribution of Illiterate Population of the RSFSR Regions by Sex and Age]. URL: http:// www.demoscope.ru/weekly/ssp/rus_ill_39.php?reg. (accessed 18 April 2018).

8. Vsesoyuznaya perepis naseleniya $1939 \mathrm{~g}$. Chislennost gorodskogo naseleniya SSSR po gorodskim poseleniyam i vnutrigorodskim rayonam [The All-Union Population Census of 1939. The Number of Urban Population of the USSR in Urban Settlements and IntraCity Districts]. URL: http://www.demoscope.ru/weekly/ ssp/rus pop 39 3.php. (accessed 18 April 2018).

9. Vsesoyuznaya perepis naseleniya $1939 \mathrm{~g}$. Chislennost nalichnogo naseleniya SSSR po rayonam i gorodam [The All-Union Population Census of 1939. The Number of Existent Population of the USSR in the Districts and Cities]. URL: http:// www.demoscope.ru/weekly/ssp/rus_pop_39_2.php. (accessed 18 April 2018).

10. Vsesoyuznaya perepis naseleniya $1939 \mathrm{~g}$. Natsionalnyy sostav naseleniya rayonov, gorodov $i$ krupnykh sel RSFSR [The All-Union Population Census of 1939. National Composition of the Population of Districts, Cities and Large Villages of the RSFSR]. URL: http://www.demoscope.ru/weekly/ssp/rus_nac_ 39 ra.php?reg=2215. (accessed 18 April 2018).

11. Vsesoyuznaya perepis naseleniya $1959 \mathrm{~g}$. Chislennost nalichnogo naseleniya gorodov i drugikh poseleniy, rayonov, rayonnykh tsentrov $i$ krupnykh selskikh naselennykh mest na 15 yanvarya 1959 goda po respublikam, krayam i oblastyam RSFSR [The AllUnion Population Census of 1959. The Number of Existent Population of Cities and Other Settlements, Areas, District Centers and Large Countryside as of the $15^{\text {th }}$ of January 1959 in the Republics, Territories and Regions of the RSFSR.]. URL: http://www.demoscope.ru /weekly/ssp/rus59_reg1.php. (accessed 18 April 2018).

12. Pavlova T.A. Zasekrechennaya tragediya: grazhdanskoe naselenie $v$ Stalingradskoy bitve [Secret Tragedy: the Civilian Population in the Battle of Stalingrad]. Volgograd, Peremena Publ., 2005. 594 p. 


\section{ОТЕЧЕСТВЕННАЯ ИСТОРИЯ}

13. RSFSR. Administrativno-territorialnoe delenie kraev, oblastey $i$ avtonomnykh respublik na 17 yanvarya 1939 goda [The RSFSR. The Administrative-Territorial Division of Territories, Regions and Autonomous Republics as of the $17^{\text {th }}$ of January 1939]. Moscow, 1939. $160 \mathrm{p}$.

14. Stalingradskaya bitva. Iyul 1942 - fevral 1943: entsiklopediya [The Battle of Stalingrad. July
1942 - February 1943: Encyclopedia]. Volgograd, Izdatel Publ., 2012. $800 \mathrm{p}$.

15. Stalingradskaya oblast (1939-1943). Tsifry i fakty: informatsionno-statisticheskiy spravochnik [The Stalingrad Region (1939-1943). Figures and Facts: an Information and Statistical Reference Book]. Volgograd, Izdatel Publ., 2016, vol. $1.424 \mathrm{p}$.

\section{Information about the Author}

Sergey G. Sidorov, Doctor of Sciences (History), Professor of Department of Russian and World History, Archaeology, Volgograd State University, Prosp. Universitetsky, 100, 400062 Volgograd, Russian Federation, sergei.sidorov@volsu.ru, https://orcid.org/0000-0002-1366-5787

\section{Информация об авторе}

Сергей Григорьевич Сидоров, доктор исторических наук, профессор кафедры отечественной и всеобщей истории, археологии, Волгоградский государственный университет, просп. Университетский, 100, 400062 г. Волгоград, Российская Федерация, sergei.sidorov@volsu.ru, https://orcid.org/ 0000-0002-1366-5787 